\section{ARTICLE}

\title{
Statutory wills: doing the right thing under the Mental Capacity Act 2005
}

\author{
Kathryn Milward, Martin Curtice \& Rosie Harding
}

Kathryn Milward is an ST5 trainee in old age psychiatry currently working in an older adult community mental health team in Birmingham and Solihull Mental Health NHS Foundation Trust. She is the 2016-2017 chair of the Royal College of Psychiatrists' Psychiatric Trainees' Committee. Martin Curtice is a consultant in old age psychiatry with Worcestershire Health and Care NHS Trust at New Haven, Princess of Wales Community Hospital, Bromsgrove. He obtained a Master of Laws with Distinction in Mental Health Law in 2003 and has an interest in mental health law, the European Convention on Human Rights in clinical practice and legal aspects of end-of-life care. Rosie Harding is Professor of Law and Society at Birmingham Law School, University of Birmingham, and Vice Chair of the Socio-Legal Studies Association. Her research focuses on the everyday regulation and legal recognition of intimate and caring relationships. Her work is grounded in questions about care, capacity and family law.

Correspondence Dr Kathryn Milward, Birmingham and Solihull Mental Health NHS Foundation Trust, Ashcroft Unit, The Moorings, Hockley, Birmingham, B18 5SD. Email: kathrynmilward@doctors. org.uk

\section{Copyright and usage}

(C) The Royal College of Psychiatrists 2017.

\begin{abstract}
SUMMARY
Statutory wills are made under the Mental Capacity Act 2005 (MCA) for persons who lack testamentary capacity. Mental health practitioners are likely to be familiar with many of the provisions of the MCA and the test for testamentary capacity. However, they may not have encountered statutory wills. This article explains the procedure for applying for a statutory will, including the role of medical practitioners. Salient legal cases are summarised to highlight the difficulties in applying a best interests framework for decision-making in the context of statutory wills. Finally, this article considers how the United Nations Convention on the Rights of Persons with Disabilities (CRPD) might affect not only on statutory wills, but also the wider provisions of the MCA.
\end{abstract}

\section{LEARNING OBJECTIVES}

- Be able to explain statutory wills and the application procedure to a patient or carer

- Understand the differences between the test for testamentary capacity (as established in Banks v Goodfellow (1870)) and assessing capacity under the MCA

- Appreciate how the CRPD might affect the decision-making process, not only for statutory wills but for all decisions made under the MCA

\section{DECLARATION OF INTEREST}

None

The principles and applications of the Mental Capacity Act 2005 (MCA) have been increasingly embedded in clinical practice since it came into force in England and Wales in 2007. Although matters regarding assessing capacity to consent, best interests decisions, lasting powers of attorney (LPAs) and deprivation of liberty safeguards are commonplace for many practitioners, the MCA also applies to the small but significant area of making a will.

The test for assessing capacity to make a will (testamentary capacity) was established in Banks v Goodfellow (1870) (Box 1). This test has survived the introduction of the MCA, which has a more wide-ranging approach to mental capacity. This is illustrated by the judgment in Re Walker (deceased) (unreported 2014)) (Box 2). The threshold for testamentary capacity is, in law, relatively lower than that set out in the MCA. However, in cases where testamentary capacity is absent, wills can be made under the MCA.

\section{Statutory wills and the MCA}

Chapter 9 of the MCA makes provisions for individuals who lack capacity. A key component was the formation of the Court of Protection, whose powers are exercised under the Act (Chapter 9, Part 2). This court has the ability to make decisions on financial, health and welfare matters for persons who lack the relevant capacity. Its responsibilities include the appointment of deputies and decisionmaking regarding deprivation of liberty orders. The Court of Protection also has the power to make wills. Wills made by the Court of Protection under the MCA for persons who lack testamentary capacity are referred to as statutory wills.

Statutory wills are very relevant to the practice of psychiatry, as many psychiatric patients lack testamentary capacity. Statutory wills can be made when a person has never possessed testamentary capacity, for example owing to intellectual disability. They can also be made if testamentary capacity has been lost, for example as a consequence of dementia, acquired brain injury or severe and enduring mental illness. Where a statutory will is made on behalf of a person who has never made a will before, this may be because

BOX 1 Summary of the test for testamentary capacity

The testator should understand:

- the nature and effect of making a will

- the extent of the estate

- the claims of those who might expect to benefit from the will (those who are being included and excluded from the will).

The testator should not:

- have a mental illness that influences him or her to make a disposition that would not otherwise have been made. (After Banks v Goodfellow (1870)) 
BOX 2 Outline of Re Walker (deceased)

Mrs Walker was diagnosed with a terminal metastatic brain tumour in 2009. Her last will was executed in January 2010, approximately 6 weeks before her death.

Following her death, her daughters challenged the will on the grounds that she did not have capacity to make it and did not know of, or approve, its contents.

The judge recognised that there were doubts as to whether Mrs Walker had fully understood the ramifications of the will. This highlighted discrepancies between the common law test for testamentary capacity established in Banks $\mathrm{V}$ Goodfellow (1870) and the Mental Capacity Act 2005 (MCA). The test for testamentary capacity does not require the testator to foresee the consequences of their decision. However, the MCA requires an ability to comprehend decisions' consequences.

After a consideration of relevant legislation, including the MCA, the judge stated:

'the correct and only test for testamentary capacity, where what is in issue is the validity of the will executed by the deceased, is the common law test set out in Banks'

The judge found that Mrs Walker had had testamentary capacity and ultimately upheld her will.

(Re Walker (deceased) (unreported 2014)

testamentary capacity has never been present or because the person failed to make a will before testamentary capacity was lost.

Statutory wills can also be made when a will already exists. Applications for statutory wills can be made when there are concerns about the relevance of the pre-existing will. This is often due to a change in the person's or potential beneficiaries' circumstances, including a change in their relationships. In cases where the validity of a pre-existing will is questioned (for instance if testamentary capacity was absent when the will was made), it is not unreasonable to presume that a statutory will might be an option. However, the judge in Re D (Statutory Will), VAC v JAD \& Ors [2010] referred to the words of a judge who had presided over an earlier hearing, who had stated:

'It is only the role of the Court of Protection to authorise a statutory will when there has been a material change of circumstances or there is a vacuum. It is not the role of this Court to adjudicate upon disputes as to the validity of wills.'

\section{How to apply for a statutory will}

An application to make a statutory will is made to the Court of Protection. The applicant must seek permission from the Court of Protection to apply unless they are a deputy appointed by the Court, or an 'attorney' under an enduring power of attorney (EPA) or LPA. Others who do not need permission are beneficiaries under the current will, those who would inherit under intestacy or individuals for whom the person might be expected to provide if he or she had capacity (Court of Protection 2007). In practice, the person's attorney under an LPA or appointed deputy usually makes the application. Application guidance and relevant forms are available online (Court of Protection 2015a), but it is advisable to seek legal advice before making an application.

Alongside the completed forms, numerous supporting documents must be submitted. These include information on the person's assets, income and expenditure, copies of any existing will, the proposed will and family details. Respondents must also be identified and notified of an application. Respondents must include all beneficiaries under the existing will, proposed beneficiaries under the new will and potential beneficiaries should the person die intestate. This is not an exhaustive list and potential applicants should refer to the Court of Protection Practice Direction 9F (Court of Protection 2015b). An assessment of capacity (COP 3) form must be completed by a medical practitioner and submitted to the court together with the other relevant forms and supporting information (Court of Protection 2015a).

Submitting an application for a statutory will currently costs $£ 400$ (plus $£ 500$ if the court holds a hearing). Further costs may include solicitor's fees, fees to medical practitioners for completing a COP 3, counsel's fees and hearing costs (Court of Protection 2015a). There is a general rule that costs can be reclaimed from the estate of the person for whom the application is being made. However, in certain circumstances the court may depart from this rule. Departing from the general rule involves consideration of several factors, including the conduct of the parties and whether making a statutory will application is felt to be reasonable (Court of Protection 2007).

If the application is straightforward and unopposed, the Court of Protection may approve it without a hearing. However, if the applicant and respondents fail to reach an agreement, a hearing will be conducted. A finalised statutory will is executed in the same way as a normal will. After the person's death, it is treated as if the person had made the will him- or herself (Court of Protection 2015a).

\section{Applications and orders for statutory wills}

Since 2010 there has been a clear upward trend in annual applications and court orders under the 
MCA (Ministry of Justice 2015a). The Ministry of Justice does not publish the precise number of statutory wills authorised by the Court of Protection. However, grouped statistics relating to the number of applications and court orders 'to execute wills, apply for gifts and orders for settlement' are published. Annual court orders to execute wills, apply for gifts and orders for settlement have dropped despite annual applications for them remaining steady (Table 1) (Ministry of Justice 2015b).

Applications and orders for statutory wills currently form only a small proportion of the total applications and orders made under the MCA. The greatest number of applications consistently relates to the appointment of a property and affairs deputy. For example, in 2014 a total of 26272 applications were made to the Court of Protection. Only 598 were applications to execute wills, apply for gifts and orders for settlement, compared with 15796 applications for the appointment of a property and affairs deputy (Ministry of Justice 2015a).

As of 31 March 2015 there were 1292897 LPA applications registered in England and Wales (Ministry of Justice 2015b). The number of LPA applications received by the Office of the Public Guardian (OPG) has increased year on year since 2008. In the first quarter of 2015 the OPG received 120010 LPA applications, an increase of $42 \%$ on the same quarter in 2014 (Ministry of Justice 2015a). This illustrates how knowledge and utilisation of the provisions under the MCA have become far more widespread. Consequently, it is possible that numbers of statutory wills will also increase.

\section{The development of statutory wills}

Statutory wills have been available in English law since 1969, when the Administration of Justice Act
1969 inserted into the Mental Health Act 1959 provision to execute a will on behalf of a person who lacked testamentary capacity. The power was re-enacted in the Mental Health Act 1983, then transferred to the MCA 2005. However, the power of the court to order the execution of statutory wills under the relevant legislation did not affect the legal test for testamentary capacity established in Banks v Goodfellow (1870).

The approach used by the courts prior to the MCA has been described as 'substituted judgment'. This required the court to take a personal and subjective perspective, rather than an impersonal and objective view. The aim was to make the decision that the person would have made themselves if they had capacity (Lush 2014).

R.H. has written a comprehensive summary of the historical development of statutory wills (Harding 2015). In case law from 1969 until the MCA came into force in 2007, statutory wills were written to reinstate earlier settled testamentary wishes following a change in circumstance (e.g. Re $D(J)$ (Court of Protection) [1982]) and also to make provision where there was no pre-existing will as testamentary capacity had always been absent (e.g. Re C (a patient) [1991]).

\section{Statutory wills following the MCA}

The legal power to make statutory wills is now contained within the MCA, under section 18 of the Act, entitled 'Section 16 powers: property and affairs', in paragraph (1)(i): 'the execution for $\mathrm{P}$ of a will'. The MCA provides a framework for best interests decision-making under section 4 . However, applying this framework to statutory wills has not been straightforward. This is demonstrated in case law, specifically Re P[2009], $\operatorname{Re} M$ [2009], Re D [2010], Re JC [2012], NT v FS [2013] and Re Meek [2014].

Summary casework statistics: applications and orders made in England and Wales annually 2008-2014

\begin{tabular}{|c|c|c|c|c|}
\hline Year & $\begin{array}{l}\text { Applications made } \\
\text { under the MCA }\end{array}$ & $\begin{array}{l}\text { Orders made } \\
\text { under the MCA }\end{array}$ & $\begin{array}{l}\text { Applications to execute wills, } \\
\text { apply for gifts and orders for } \\
\text { settlement, including those where } \\
\text { there is an EPA or LPA }\end{array}$ & $\begin{array}{l}\text { Orders to execute wills, apply for } \\
\text { gifts and orders for settlement, } \\
\text { including those where there is } \\
\text { an EPA or LPA }\end{array}$ \\
\hline 2008 & 22583 & 16407 & 711 & 301 \\
\hline 2009 & 19093 & 15043 & 593 & 351 \\
\hline 2010 & 20459 & 17798 & 517 & 345 \\
\hline 2011 & 23538 & 22797 & 550 & 547 \\
\hline 2012 & 24877 & 20043 & 589 & 319 \\
\hline 2013 & 24923 & 21895 & 644 & 217 \\
\hline 2014 & 26272 & 23400 & 598 & 199 \\
\hline
\end{tabular}

EPA, enduring power of attorney; LPA, lasting power of attorney; MCA, Mental Capacity Act 2005

Source: Ministry of Justice (2015b: Tables 15 and 16). 


\section{$\operatorname{Re} P$ [2009]}

The first statutory will executed under the MCA was in $\operatorname{Re} P$ [2009]. P was living in California and had immovable property in England and Wales. Information about P's circumstances is absent from this judgment, although it states: 'There is no doubt that he now lacks mental capacity'.

In summarising legislation prior to the MCA, the judge recognised that 'substituted judgement' approaches had been utilised. However, when describing the general philosophy of the MCA he stated:

'any decision made on behalf of $\mathrm{P}$ must be made in P's best interests. This is not (necessarily) the same as inquiring what $\mathrm{P}$ would have decided if he or she had had capacity.'

He then quoted from the explanatory notes to the MCA (HM Government 2005):

'Best interests is not a test of "substituted judgement" (what the person would have wanted), but rather it requires a determination to be made by applying an objective test as to what would be in the person's best interests.'

This highlighted the different approach required for decision-making following introduction of the MCA. Furthermore, the judge made it clear that guidance given under the Mental Health Acts 1959 and 1983 regarding wills was no longer applicable to decisions being made under the MCA.

Within this judgment, the judge questioned how to determine a person's best interests for the purposes of creating a will, when a will has effect only after death. In answering this, he stated:

'for many people it is in their best interests that they be remembered with affection by their family and as having done "the right thing" by their will.'

He went on to state that this premise could be taken into account when assessing P's best interests in making a statutory will. Ultimately, the judgment stated that a structured decisionmaking process, as laid down by the MCA, was followed in order to execute a statutory will on behalf of $\mathrm{P}$.

\section{$\operatorname{Re} M$ [2009]}

$\mathrm{M}$ was a childless widow who lacked testamentary capacity. She had lived with $\mathrm{Z}$ and his family for 4 years. During this period, $M$ transferred at least $£ 177041$ to Z. During proceedings in the Family Division, $\mathrm{Z}$ failed to give a proper account of what came of this money. Consequently, it was directed that $\mathrm{M}$ should not live with $\mathrm{Z}$ or have any contact with him or his family. $M$ had made a will shortly after moving in with $\mathrm{Z}$, making $\mathrm{Z}$ the sole beneficiary to her estate. However, previous wills had divided her estate between charities and a neighbour.
Following a hearing in the Court of Protection, the judge authorised a statutory will for M. This effectively reinstated her earlier testamentary wishes, dividing her estate between charities and her neighbour; no provision was made for $\mathrm{Z}$.

In his judgment, the judge took a similar approach to that in $\operatorname{Re} P$. He emphasised the importance of the 'structured decision-making process' prescribed by the MCA. He also concurred that authorities on statutory wills prior to the MCA were indeed 'best consigned to history'. Furthermore, he noted that 'best interests do not cease at the moment of death'.

The judgment in $\operatorname{Re} M$ has had an impact on subsequent statutory will cases, as the judge considered how individual factors should be weighted when determining best interests. He said:

'the weight to be attached to the various factors will, inevitably, differ depending upon the individual circumstances of the particular case. A feature or factor which in one case may carry great, possibly even preponderant, weight may in another, superficially similar, case carry much less, or even very little, weight.'

This included the weight to be attached to the person's wishes and feelings, which he stated 'will always be case-specific and fact-specific'. Furthermore, he described the importance of 'magnetic factors' that affect, or determine, the outcome, and gave various 'magnetic factors' to demonstrate why $\mathrm{Z}$ should not benefit from M's will.

\section{$\operatorname{Re} D$ [2010]}

In this case there were concerns about the validity of a pre-existing will. Mrs D was a widow who had suffered a stroke in 2003 that subsequently affected her communication. The judgment addressed the question of whether or not the Court of Protection should intervene in disputes about the validity of wills.

The applicant, Mrs C (the eldest daughter of Mrs D), argued that there had been a 'material change of circumstances' since the last will. Specifically, that proposed beneficiaries of the disputed will, Mr D (son) and Mrs S (another daughter), had previously acted in their own interests rather than the interests of Mrs D. An EPA naming Mr D had been found to be a forgery. Furthermore, Mr D and Mrs S had been instructed to return money and investments held by them on behalf of Mrs D to the deputy (a solicitor appointed to look after property and financial affairs).

The statutory will application was permitted, as it was felt that there was a 'significant issue of interpretation' under the MCA that needed to be addressed, namely, whether a statutory will was in 
a person's best interests when there were questions about the validity of a recent will that departed from the terms of an earlier will. In his judgment, the judge stated that it was inappropriate for him to rule on the validity of wills. However, he said that it was in Mrs D's best interests for him to order the execution of a statutory will that reflected earlier, undisputed testamentary wishes. He went on to state that this would avoid 'her memory [being] tainted by the bitterness of a contested probate dispute' and that 'Mrs D's family will be able to remember her as having done the "right thing" by her last will'.

\section{Re JC [2012]}

JC, who had a diagnosis of mixed dementia, had an estate valued at $£ 3500000$. He was the biological father of four children, A, B, C and D, although he had consistently denied that he was the father of A. JC had limited contact with B and C throughout their lives. The youngest child, D, had been adopted shortly after birth and had never met JC. According to adoption law, a child becomes the child of the adoptive parents and would not inherit from biological parents on intestacy. An earlier statutory will directed that JC's estate be divided among the persons who would inherit if JC died intestate, namely A, B and C.

D applied for a statutory will that would divide JC's estate equally between the four children. She argued that JC had abandoned responsibility for all his children at an early stage of their lives and that he had 'unusually distant and non-fatherly relationships' with each of them. Finally, she argued that equal division of the estate into four was 'the right thing' and therefore in JC's best interests.

In his judgment, the judge considered that best interests actually contain a strong element of substituted judgement. He stated that if substituted judgement was applied, he believed that JC would have chosen to die intestate. However, he felt that a statutory will was in JC's best interests. He also doubted that doing the 'right thing' was of assistance in this case. He said:

'JC has an appalling track record. He has spent his entire lifetime doing precisely "the wrong thing" in his relationships.'

D's application was dismissed and a statutory will was executed dividing the estate according to intestacy rules. The judge said that the factor of magnetic importance in this case was the absence of a relationship between JC and D. He stated that, had D formed a relationship with JC, it was likely he would have authorised a statutory will that made some provision for her.

\section{NT v FS [2013]}

In this case, $\mathrm{F}$ had a diagnosis of Alzheimer's dementia and his estate was valued at about $£ 3100000$. There were multiple respondents to the statutory will application, reflecting his complex family relationships. They included his son, mother, siblings and cohabiting partner.

The judge authorised a statutory will to be executed dividing the estate between beneficiaries in varying proportions. The division of the estate reflected the nature of the beneficiaries' relationship with $\mathrm{F}$, but also how the beneficiary contributed to F's estate. The judgment details the type of relationship $\mathrm{F}$ had with each beneficiary. It also includes F's financial position and that of two beneficiaries. The different views held by the parties regarding the proposed division of the estate are also detailed.

When considering best interests, the views of those caring for the person or interested in his or her welfare should be sought in accordance with section 4 of the MCA. However, this judgment does not detail any attempts to involve $\mathrm{F}$ in the decisionmaking process. The person's previously held wishes should also be considered. There was an invalid will thought to have been made in the mid1980s. Despite the judge stating that he believed that $\mathrm{F}$ thought this will was valid, it was not regarded as a 'magnetic factor' or a starting point for determining F's best interests. Interestingly, early in the judgment the judge said that he did not intend to place any weight on having done the 'right thing', which appeared contrary to the approach taken in $\operatorname{Re} P$ [2009].

\section{Re Meek [2014]}

This case referred to Gladys Meek, a widow with vascular dementia. She had no pre-existing will and, had she died intestate, her niece and greatnephew would have inherited her estate. Mrs Miller and Mrs Johnson (relatives of her deceased husband) had been appointed as deputies for property and affairs. However, they had been removed as they had made extravagant gifts to charities, themselves and other family members. Mrs Miller and Mrs Johnson accepted that they owed $£ 250000$ to Mrs Meek.

The judge hearing the statutory will application stated:

'I have to prepare a balance sheet of the various factors for and against the identification of the proposed beneficiaries under the statutory will.'

Subsequently, he detailed relevant factors for and against the inclusion of proposed beneficiaries in the statutory will. For example, when considering whether Mrs Miller and Mrs Johnson should be 
beneficiaries, he acknowledged their past and continued involvement in her care. He stated that they had 'abused the trust that they assumed in the most spectacular manner'. Ultimately, an order for a statutory will was made providing for a family friend and her daughter, with the remainder of the estate passing to charities. Mrs Miller, Mrs Johnson and the relatives who would have benefited under intestacy were excluded from the statutory will.

The judge in this case provided an in-depth commentary on the concept of doing 'the right thing' in authorising a statutory will, as proposed in $\operatorname{Re} P$. He stated:

\begin{abstract}
" "the right thing" is to be judged from the perspective, not of any relatives or friends who may be competing for a share of the incapacitous person's testamentary bounty, but rather from the perspective of the well-informed, and disinterested, objective bystander. Nevertheless, "the right thing" is to be judged [...] by reference to the standards of the incapacitous person himself, and not by what the reasonable incapacitous person might be thought to think.'
\end{abstract}

However, in the recent case of Re Jones [2014] it was noted that some judges find employing the 'doing the right thing' concept helpful, whereas others do not.

\section{Scotland and Northern Ireland}

As the MCA applies only to England and Wales, different legislation applies in Scotland and Northern Ireland. In Northern Ireland, courts have powers to execute statutory wills on behalf of patients under Part VIII of the Mental Health (Northern Ireland) Order (1986).

Lush (2014) describes Scotland as resisting the implementation of jurisdiction for the creation of statutory wills. He refers to a report by the Scottish Law Commission (1990: para. 4.78), which stated:

'In Scotland no one has power to make a will for a person who lacks testamentary capacity. Indeed, [...] the idea that someone else can make a will for anyone seems absurd.'

Subsequently, the Adults with Incapacity (Scotland) Act 2000 did not give Scottish judges powers to authorise statutory wills. However, Lush (2014) describes a practice whereby sheriffs have occasionally authorised 'intervention orders' that have testamentary effect. This practice was acknowledged by the Scottish Law Commission (2009: para. 6.50), which stated:

\footnotetext{
'we note that since 1990 there have been legislative changes [...] with the passage of the Adults with Incapacity (Scotland) Act 2000. Part 6 of this Act provides for "intervention orders", which allow a court to make an order relating to an incapable person's property, financial affairs or personal
}

welfare. These have, on occasion, been made for succession purposes.'

Scottish law on inheritance and succession is quite different in many respects, as there is not the same level of testamentary freedom as prevails in the rest of the UK. It is unlikely that the concept of the 'statutory will' would find favour in Scotland. England, Wales and Northern Ireland are part of only a small number of countries that allow statutory wills (Harding 2015).

\section{The United Nations Convention on the Rights of Persons with Disabilities}

The United Nations (UN) Convention on the Rights of Persons with Disabilities (CRPD) is an international treaty that identifies the rights of people with disabilities. States party to the convention must promote, protect and ensure these rights. The UN General Assembly adopted it on 13 December 2006. The UK is legally bound to respect the standards within it following its ratification on 8 June 2009.

Article 12 of the CRPD states that persons with disabilities have the right to equal recognition before the law. This includes a right to enjoy legal capacity on an equal basis to others and the right to control their own financial affairs. Safeguards should ensure that measures relating to legal capacity respect the rights, will and preferences of the person. Further guidance on Article 12 is provided by the Committee on the Rights of Persons with Disabilities (2014: para. 4):

'there has been a general failure to understand that the human rights-based model of disability implies a shift from the substitute decision-making paradigm to one that is based on supported decision-making.'

Article 12 mandates that persons with disabilities be supported in exercising legal capacity. The primary purpose is to ensure that the person's rights, will and preferences are respected. However, the Committee also said (para. 21):

'Where, after significant efforts have been made, it is not practicable to determine the will and preferences of an individual, the "best interpretation of will and preferences" must replace the "best interests" determinations.'

Furthermore (para. 21):

'The "best interests" principle is not a safeguard which complies with Article 12 in relation to adults.'

This interpretation of Article 12 of the CRPD sits in opposition to interpretations of the appropriate approach to best interests under the MCA that has been suggested in some statutory wills cases. If the MCA is to be fully compliant with the CRPD, then the approach to best interests under that legislation may need to shift. In summary, in 
TABLE 2 Differences between legal requirements for testamentary capacity and the test for capacity under the Mental Capacity Act 2005

\begin{tabular}{|ll|}
$\begin{array}{l}\text { Legal requirements for } \\
\text { testamentary capacity } \\
\text { (defined by Banks } \mathbf{v} \text { Goodfellow (1870)) }\end{array}$ & $\begin{array}{l}\text { Test for capacity under the } \\
\text { Mental Capacity Act 2005 }\end{array}$ \\
\hline $\begin{array}{l}\text { Shifting burden of proof regarding capacity } \\
\begin{array}{l}\text { The will must represent the testator's } \\
\text { intentions and an appreciation of the claims } \\
\text { to which he or she should (or would be } \\
\text { expected to) give effect }\end{array}\end{array}$ & $\begin{array}{l}\text { The testator must understand, retain, use } \\
\text { or weigh all the information relevant to the } \\
\text { decision (section 3(1)) }\end{array}$ \\
\hline $\begin{array}{l}\text { The testator does not need to foresee the } \\
\text { consequences of the decision }\end{array}$ & $\begin{array}{l}\text { Requires that the testator has the ability } \\
\text { to comprehend the reasonably foreseeable } \\
\text { consequences of the decision (section 3(4)) }\end{array}$ \\
\hline
\end{tabular}

order for statutory wills to comply with the CRPD, the best interests approach must be replaced by supported decision-making. Only when supported decision-making fails, despite exhaustive efforts, to determine the will and preferences of the person, should there be a 'best interpretation of will and preferences'. A core principle of the MCA is decision-making in best interests; this is incompatible with the CRPD.

Article 4 of the CRPD obligates that states party to the convention should develop and implement policies and laws that secure these rights and abolish laws that constitute discrimination. Consequently, the CRPD will have an impact on the UK's legal frameworks. This includes not only statutory wills, but all the provisions under the MCA.

\section{Discussion}

\section{Testamentary capacity and the MCA}

The MCA has had far-reaching implications for legal and clinical practice. Despite this, the introduction of the MCA has not changed the approach to assessing testamentary capacity. The judge in the case of Re Walker (deceased) (unreported 2014) (Box 2) questioned whether common law on testamentary capacity (as established in Banks v Goodfellow (1870)) had been replaced by the provisions of the MCA. However, he ruled that in this instance, the correct and only test for testamentary capacity remained the common law test set out in Banks v Goodfellow.

The test for capacity under the MCA and the legal requirements for testamentary capacity differ (Table 2). The legal threshold for testamentary capacity is relatively lower than that set out in the MCA. Consequently, there may be individuals who possess testamentary capacity in law, but might be considered to lack capacity if assessed using the test defined by the MCA. Statutory wills are an option for those who lack testamentary capacity as defined by Banks v Goodfellow.

\section{Statutory wills must reflect the best interests of} the person

The MCA requires that statutory wills are written in the best interests of the person. It also provides a framework for best interests decision-making. This structured decision-making process should underpin the approach when deciding the outcome of a statutory will and all best interests decisions under the MCA. However, case law to date suggests that this process has not been consistently followed, as judges have used different approaches to assessing best interests when authorising statutory wills.

The Supreme Court has provided guidance on best interests decision-making under the MCA. The first MCA case to come before it regarded the best interests assessment in a case involving end-of-life care and treatment (Aintree University Hospitals NHS Foundation Trust v James [2013]). This judgment affirmed that the core purpose of the best interests test was 'to consider matters from the patient's point of view' and 'to consider his best interests in a holistic way'. However, it accepted that it would not always be possible to ascertain what someone's views were in the past. Furthermore, even when previous views had been ascertained, the current stresses and strains of the issue at hand may well have changed them. The judgment also emphasised the importance of seeking views from relevant others within the best interests process.

\section{Difficulties with best interests decision-making}

In an in-depth review of statutory wills and best interests, R.H. considered three problematic elements of paternalism inherent in best interests decision-making (Harding 2015). First, the patient's views are often minimised in favour of a 'doctor-knows-best' approach, which is described as 'woefully out of step with contemporary understandings of the importance of patient autonomy'. Second, best interests decisions can act as a 'smokescreen', hiding other reasons for a particular decision, including the social and cultural values of the decision maker. Third, best interests decision-making 'denies legal capacity to make decisions on the basis of impairments in mental capacity'.

\section{'Best interests' is a contested concept in international mental capacity and disability law}

Best interests decision-making can be argued as contravening Article 12 of the CRPD as it interferes with the right of persons with disabilities to receive equal treatment before the law. To illustrate this, R.H. has discussed controversial decisions in 
BOX 4 Key features of the Convention on the Rights of Persons with Disabilities (CRPD)

\section{Article 12 of the CRPD}

States that persons with disabilities have the right to equal recognition before the law:

- therefore, persons with disabilities must be supported in exercising legal capacity

- this requires replacing the best interests approach with supported decision-making

- if supported decision-making is not practicable, the 'best interpretation of will and preferences' must be applied.

\section{Article 4 of the CRPD}

Obligates countries that ratify the convention (including the UK) to develop and implement policies and laws to secure these rights

Impact of the CRPD on the Mental Capacity Act 2005 (MCA)

The CRPD has far-reaching implications:

- best interests decision-making is a core principle of the MCA

- the CRPD is applicable to all provisions of the MCA, not only statutory will decisions.

which the Court of Protection has written a will in the 'best interests' of a person who has never possessed testamentary capacity (Harding 2015). She observes that, in such cases, courts have been 'relatively creative in their reasoning, in order to justify legacies to charities and other departures from the rules of intestate succession'.

Key features of the CRPD relevant to clinicians are listed in Box 4.

It will be interesting to see how case law on statutory wills evolves over time. Lush (2014), a senior judge of the Court of Protection, stated that we had not yet fully felt the impact of the next major development in the evolution of the statutory will, namely the CRPD. The CRPD advocates replacing best interests decision-making with supported decision-making. If supported decisionmaking fails, there should be a 'best interpretation of will and preferences'. If supported decisionmaking is applied, Lush (2014) predicted that the key issue would not be the presence or absence of testamentary capacity, but whether the person could be supported to exercise their legal right to make a will for themselves. He also considered the enormity of this challenge to everyone, especially those in the medical profession, the legal profession and 'not least, the judges of the Court of Protection'.

\section{Key implications for clinicians}

Despite concerns regarding the CRPD and inconsistencies in applying best interests decisionmaking to statutory will decisions, reviewing salient case law on statutory wills has identified key implications for clinicians (Box 5).

There has been a steady increase in LPA applications since the inception of the MCA. It is likely that there will be a concomitant and steady increase in the numbers of statutory wills made in the future, albeit the current rate relative to LPAs remains very low. It is important that all clinicians have a good understanding of statutory wills and the application procedure, particularly if they are supplying a COP 3 form. Clinicians should also routinely encourage patients to consider making a will, to try to avoid the need for a statutory will at a later date. This would reduce the likelihood of future legal disputes and costly applications to the Court of Protection in the event of testamentary capacity being lost.

\section{BOX 5 Statutory wills - key implications for clinicians}

Statutory wills can be made for people who lack testamentary capacity (as defined by Banks v Goodfellow (1870)).

The Mental Capacity Act 2005 (MCA) requires that statutory wills are written in the best interests of the person:

- despite inconsistent approaches to applying the best interests framework, statutory will decisions are underpinned by section 4 of the MCA.

Case law has demonstrated three scenarios in which statutory will applications are made:

- the person has never possessed testamentary capacity (e.g. people with intellectual disability)

- the person possessed testamentary capacity but never made a will; they then lost testamentary capacity (e.g. people with dementia, acquired brain injuries or severe and enduring mental illness).

- the person possessed testamentary capacity and made a will, but subsequently lost capacity and their circumstances changed.

Applications for statutory wills are made at the Court of Protection (COP)

A doctor must be involved to complete and provide an assessment of capacity (COP 3) form.

In assessing best interests, courts may use a balancesheet approach. This identifies the various factors for and against inclusion of beneficiaries in a statutory will. Such an approach is advocated for clinicians to use in clinical practice, particularly in complex cases.
MCO answers

$1 d \quad 2 c \quad 3$ e $\quad 4 b \quad 5 c$ 


\section{References}

Committee on the Rights of Persons with Disabilities (2014) General Comment No. 1. Article 12: Equal Recognition before the Law. Office of the United Nations High Commissioner for Human Rights (http://www. ohchr.org/EN/HRBodies/CRPD/Pages/GC.aspx). Accessed 17 September 2016

Court of Protection (2007) Mental Capacity, England and Wales: The Court of Protection Rules (Statutory Instrument No. 1744 (L. 12). TSO (The Stationery Office) (http://www.legislation.gov.uk/uksi/2007/1744/ pdfs/uksi_20071744_en.pdf).

Court of Protection (2015a) Make a statutory will on behalf of someone else. gov.uk (https://www.gov.uk/apply-statutory-will/print). Accessed 17 September 2016

Court of Protection (2015b) Practice Direction 9F: Applications Relating to Statutory Wills, Codicils, Settlements and Other Dealings with P's Property (Effective from July 2015). Courts and Tribunals Judiciary (https://www.judiciary.gov.uk/wp-content/uploads/2015/06/copd-pd-9fwills1.pdf).

Harding R (2015) The rise of statutory wills and the limits of interests decision-making in inheritance. Modern Law Review, 78: 945-70.

HM Government (2005) Section 4: Best interests. In Mental Capacity Act 2005 Explanatory Notes. Legislation.gov.uk (http://www.legislation. gov.uk/ukpga/2005/9/notes/division/6/1/2/3?view=plain). Accessed 17 September 2016.

Lush D (2014) The evolution of the statutory will jurisdiction. Elder Law Journal, 4(2): 173-80.

Ministry of Justice (2015a) Family Court Statistics Quarterly: January to March 2015. Ministry of Justice Statistics Bulletin. Ministry of Justice (https://www.gov.uk/government/uploads/system/uploads/attachment_ data/file/438048/family-court-statistics-quarterly.pdf).
Ministry of Justice (2015b) Family Court Tables: January to March. In Family Court Statistics Quarterly: January to March 2015. Ministry of Justice Statistics Bulletin. Ministry of Justice (https://www.gov.uk/ government/uploads/system/uploads/attachment_data/file/438049/ family-court-statistics-tables-q1-2015.xIs)

Scottish Law Commission (1990) Report on Succession (SLC 214). TSO (The Stationery Office) (http://www.scotlawcom.gov.uk/ files/6812/7989/6684/rep124.pdf).

Scottish Law Commission (2009) Report on Succession (SLC 215). TSO (The Stationery Office) (http://www.scotlawcom.gov.uk/ files/7112/7989/7451/rep215.pdf).

\section{Case law}

Aintree University Hospitals NHS Foundation Trust v James [2013] UKSC 67.

Banks v Goodfellow (1870) LR 5 OB 549

NT v FS [2013] EWHC 684 (COP)

Re C (a patient) [1991] 3 All ER 866.

Re $D(J)$ (Court of Protection) [1982] Ch 237

Re D (Statutory Will), VAC v JAD \& Ors [2010] EWHC 2159 (Ch) (16 August 2010).

\section{Re JC [2012] WTLR 1211}

Re Jones [2014] EWCOP 59.

Re M [2009] EWHC 2525 (Fam) (12 October 2009).

Re Meek [2014] EWCOP 1 (10 April 2014).

Re P[2009] EWHC 163 (Ch) (09 February 2009).

Re Walker (deceased) (unreported 2014) Lexis Citation 237, Chancery Division.

\section{MCOs}

Select the single best option for each question stem

\section{Regarding the legal test for testamentary} capacity:

a it has now been superseded by the Mental Capacity Act 2005 (MCA) section 3 test of capacity

b it was established in 1890

c the testator need understand only the nature of making a will

$d$ the testator should understand the extent of the estate

e the testator need understand the claims only of those being included in the will.

2 Regarding the Convention on the Rights of Persons with Disabilities (CRPD):

a Article 12 obligates countries that ratify the convention (including the UK) to develop and implement policies and laws to secure these rights

b the CRPD is applicable to all provisions of the MCA 2005 except statutory will decisions

c Article 12 states that persons with disabilities have the right to equal recognition before the law d the CRPD is only applicable to statutory wills made under the MCA

e persons with disabilities need not be supported in exercising legal capacity.

3 Regarding the evolution of statutory wills:

a statutory wills have been available in English law since 1959

b prior to the MCA 2005, statutory wills were only to be found within the Mental Health Act (MHA) 1959

c the Court of Protection can make statutory wills under both the MCA 2005 and MHA 1983

$d$ the execution of statutory wills under the MCA subsequently changed the previously established legal test for testamentary capacity

e prior to the MCA 2005, statutory wills were made under the MHA 1983.

\section{Regarding statutory wills:}

a statutory wills cannot be made when a will already exists

b statutory wills can be made when a person has never possessed testamentary capacity

c statutory wills cannot be made where testamentary capacity has been lost as a consequence of severe and enduring mental illness

d statutory wills can only be made where a will already exists

e where a statutory will is made on behalf of a person who never made a will this can only be because testamentary capacity has never been present.

\section{Regarding statutory wills:}

a an assessment of capacity (COP 3) form needs to be completed by a medical practitioner in only the most complex of cases

b a finalised statutory will is not executed in the same way as a normal will

c after a person's death a statutory will is treated as if the person had made the will themselves

$\mathrm{d}$ an application to make a statutory will is made to the local authority

e a person's attorney under an LPA or deputy rarely makes an application for a statutory will. 